Revue des patrimoines

$42 \mid 2020$

Imagerie numérique et patrimoine culturel :

représentation et transmission des connaissances

\title{
LE NUMERO EN BREF - Imagerie numérique et patrimoine culturel : représentation et transmission des connaissances
}

THE ISSUE IN BRIEF - Digital imaging and cultural heritage: representation and transmission of knowledge

Responsables scientifiques : Pascal Liévaux et Livio De Luca

\section{(2) OpenEdition}

Journals

Édition électronique

URL : http://journals.openedition.org/insitu/27308

DOI : 10.4000/insitu.27308

ISSN : 1630-7305

Éditeur

Ministère de la Culture

Référence électronique

Responsables scientifiques : Pascal Liévaux et Livio De Luca, «LE NUMERO EN BREF - Imagerie numérique et patrimoine culturel : représentation et transmission des connaissances », In Situ [En ligne], 42 | 2020, mis en ligne le 12 juin 2020, consulté le 13 janvier 2021. URL : http:// journals.openedition.org/insitu/27308; DOI : https://doi.org/10.4000/insitu.27308

Ce document a été généré automatiquement le 13 janvier 2021.

In Situ Revues des patrimoines est mis à disposition selon les termes de la licence Creative Commons Attribution - Pas d'Utilisation Commerciale - Pas de Modification 4.0 International. 


\title{
LE NUMERO EN BREF - Imagerie numérique et patrimoine culturel : représentation et transmission des connaissances
}

\author{
THE ISSUE IN BRIEF - Digital imaging and cultural heritage: representation and \\ transmission of knowledge
}

Responsables scientifiques: Pascal Liévaux et Livio De Luca

1 La richesse et la variété des contributions sélectionnées dans les deux numéros que la revue In Situ a souhaité consacrer à l'imagerie numérique appliquée au patrimoine démontre s'il le fallait à quel point ce domaine, encore émergent, offre un environnement favorable à la réalisation de travaux associant chercheurs académiques et professionnels du patrimoine au sein de programmes allant de la recherche la plus fondamentale à la plus appliquée.

2 Tout en ne prétendant pas dresser un panorama exhaustif de la recherche et des développements technologiques dans le domaine de l'imagerie numérique appliquée au patrimoine, nous avons souhaité esquisser ici un portrait, que nous espérons fidèle, d'une communauté dynamique, proposant et expérimentant des approches et des outils innovants, interrogeant sans cesse ses propres modes opératoires pour les renouveler par l'intégration de connaissances et compétences de plus en plus riches et variées.

3 Les articles sélectionnés portent sur des objets patrimoniaux très variés, monuments historiques, sites archéologique et ensembles urbains, sculptures monumentales, art pariétal, cartes, objets de toutes tailles, etc., réalisés avec les techniques et les matériaux les plus divers, appartenant aux époques les plus variées. Du fait de leur grand nombre, ils ont été répartis en deux volumes constituant deux numéros en relation à deux grands champs d'application de l'imagerie numérique: pour l'observation et l'analyse du patrimoine dans le premier ; pour la représentation et la transmission des connaissances dans le second. 
4 Les articles de ce second volume, restituent et analysent plusieurs projets dans lesquelles l'imagerie 3D, systématiquement reliée à d'autres ressources annexes, agit non seulement comme un révélateur de l'histoire et des objets que le passé nous a légués, mais aussi comme un outil de diffusion pleinement en phase avec les besoins et les attentes du XXI ${ }^{\mathrm{e}}$ siècle.

5 The richness and variety of the contributions selected in the two issues that the journal In Situ wished to devote to digital imaging applied to heritage demonstrates, if necessary, to what extent this still emerging field offers a favourable environment for carrying out work involving academic researchers and heritage professionals within programmes ranging from the most basic to the most applied research.

6 While not claiming to provide an exhaustive overview of research and technological developments in the field of digital imaging applied to heritage, we have decided to sketch here a portrait, which we hope will be a faithful one, of a dynamic community, proposing and experimenting with innovative approaches and tools, constantly questioning its own operating methods to renew them by integrating increasingly rich and varied knowledge and skills.

7 The selected articles cover a wide variety of heritage objects, historical monuments, archaeological sites and urban ensembles, monumental sculptures, cave art, maps, objects of all sizes, etc., produced using the most diverse techniques and materials, from the most varied periods. Due to their large number, they have been divided into two volumes constituting two issues related to two main fields of application of digital imaging: for the observation and analysis of heritage in the first; for the representation and transmission of knowledge in the second.

8 The articles in that second issue explain and analyses several projects in which 3D imagery is systematically linked to other additional resources and acts not only as a reminder of history and the objects left to us by the past, but also as a knowledge dissemination tool that fully matches the needs and expectations of the $21^{\text {st }}$ century. 